\title{
Diagnoza i terapia osób z centralnymi zaburzeniami przetwarzania słuchowego w Polsce
}

\section{Central Auditory Processing Disorders: diagnostic tools and therapeutic methods used in Poland}

\author{
Anna Skoczylas ${ }^{1,2}$, Katarzyna Cieśla ${ }^{1,2}$, Zdzisław Marek Kurkowski ${ }^{1,3}$, Natalia Czajka ${ }^{1,2}$, \\ Henryk Skarżyński ${ }^{1,2}$ \\ ${ }^{1}$ Instytut Fizjologii i Patologii Słuchu, ul. Zgrupowania AK „Kampinos” 1, 01-943 Warszawa \\ ${ }^{2}$ Światowe Centrum Słuchu, ul. Mokra 17, Kajetany, 05-830 Nadarzyn \\ ${ }^{3}$ Uniwersytet Marii Curie-Skłodowskiej, Lublin
}

Adres autora: Anna Skoczylas, Światowe Centrum Słuchu, Instytut Fizjologii i Patologii Słuchu, ul. Mokra 17, Kajetany, 05-830 Nadarzyn; Tel. 2235603 16, Fax. 2235603 86, e-mail: a.skoczylas@ifps.org.pl

\section{Streszczenie}

Centralne zaburzenia przetwarzania słuchowego (Central Auditory Processing Disorders, CAPD) są definiowane jako trudności z wykorzystaniem sygnału akustycznego pomimo prawidłowej czułości słuchu.

W niniejszej pracy opisane zostały przejawy tych zaburzeń oraz ich diagnoza. Przedstawione zostały także metody terapii słuchowych stosowanych na terenie Polski u osób centralnymi zaburzeniami przetwarzania słuchowego.

Słowa kluczowe: centralne zaburzenia przetwarzania słuchowego • CAPD • terapie słuchowe • terapia zaburzeń przetwarzania słuchowego $\bullet$ terapia centralnych zaburzeń przetwarzania słuchowego

\begin{abstract}
Central Auditory Processing Disorders (CAPD) are defined as difficulty in using auditory information to communicate and learn in the presence of normal peripheral hearing.
\end{abstract}

This paper discusses the symptoms of CAPD and the diagnose of the disorder but it focuses on different methods of therapy used in Poland.

Key words: Central Auditory Processing Disorders • CAPD • therapy of central auditory processing disorders

\section{Wprowadzenie}

Od lat lekarze i specjaliści z dziedzin pokrewnych wiedzą, że prawidłowo zbudowany i dobrze funkcjonujący narząd słuchu doprowadzający informacje słuchowe do mózgu nie gwarantuje prawidłowego słuchania. Zdaniem amerykańskich badaczy [Chermak \& Musiek 1997] ok. 2-3\% populacji pomimo prawidłowej czułości słuchu ma różnego rodzaju trudności słuchowe. Katz i wsp. [1992] opisali przetwarzanie słuchowe, jako „to, co robimy z tym, co słyszymy” („what we do with what we hear”). Centralne zaburzenia przetwarzania słuchowego (ang. Central Auditory Processing Disorders - CAPD) opisywane są jako niemożność pełnego wykorzystania słyszanego sygnału akustycznego przy prawidłowym jego odbiorze w strukturach obwodowych [Katz 1994].
American Speech-Language-Hearing Association (ASHA) określiło centralne procesy przetwarzania słuchowego, jako mechanizmy i procesy odpowiadające za zjawiska:

- lokalizacji i lateralizacji dźwięku,

- słuchowego różnicowania dźwięków,

- przetwarzania czasowego dźwięków, w tym: analizę (rozdzielczość) czasową, maskowanie czasowe, integrację czasową bodźców, percepcję kolejności bodźców,

- rozumienia sygnału (np. mowy) w obecności sygnału zagłuszającego,

- rozumienia sygnałów zniekształconych.

Te mechanizmy i procesy odnoszą się do wszelkiego rodzaju dźwięków, w tym dźwięków mowy (ASHA 1996). Występowanie zaburzeń można stwierdzić, jeżeli co najmniej jeden $\mathrm{z}$ tych procesów przebiega nieprawidłowo. 


\section{Przejawy centralnych zaburzeń przetwarzania słuchowego w życiu codziennym}

Centralne zaburzenia przetwarzania słuchowego w znacznym stopniu mogą wpłynąć na funkcjonowanie człowieka, zwłaszcza zaś na rozwój mowy, kompetencje komunikacyjne, czytanie i pisanie. Zaburzenia te mogą dotyczyć takich funkcji jak: odróżnianie dźwięków o podobnych częstotliwościach (np. ś-sz), wszelkie aspekty „obróbki” czasowej sygnału takie jak odróżnianie dźwięków o podobnej długości (cz-sz), percepcja kolejności dźwięków (k-o-t, k-t-o), maskowanie (gdy dźwięki np. mowy „nachodzą na siebie”, zlewają się), integrację czasową (składanie sygnałów np. głosek lub sylab w całość, jaką jest wyraz)

Osoby, u których występują centralne zaburzenia przetwarzania słuchowego mogą mieć problemy z rozumieniem mowy w hałasie (np. w klasie szkolnej, na ulicy), rozumieniem mowy zniekształconej (pogłos w pomieszczeniu, mało wyrazista artykulacja mówcy), rozumieniem dłuższych wypowiedzi, pytań, instrukcji, uczeniem się w oparciu o słuch, nauką języka obcego, zapamiętywaniem informacji podawanych drogą słuchową, robieniem notatek ze słuchu. Szybko następuje u nich zmęczenie, trudności z utrzymaniem uwagi, zwłaszcza w pomieszczeniach z pogłosem lub w hałasie. Tym osobom kłopot może też sprawiać kierowanie, utrzymywanie oraz podzielność uwagi słuchowej, zwłaszcza, jeśli w tle słychać inne dźwięki. Można też u nich zaobserwować opóźnienie reakcji na bodziec werbalny (nawet do kilku sekund) związane z powolnym przetwarzaniem usłyszanego sygnału. U dzieci dość często obserwuje się występowanie opóźnionego rozwoju mowy i zaburzeń artykulacji. Ponieważ jednak badania audiometryczne wykazują, że dzieci te słyszą prawidłowo, trudności te dość często przypisywane bywają zaburzeniom uwagi, zachowania itp.

\section{Diagnoza}

Centralne zaburzenia przetwarzania słuchowego mogą współwystępować z obwodowymi zaburzeniami słuchu. W związku z tym, konieczne jest przeprowadzenie wnikliwego wywiadu medycznego, oceny otoskopowej uszu i wykonanie badań słuchu, takich jak audiometria tonalna, audiometria słowna, audiometria impedancyjna, aby móc rozpoznać rodzaj trudności i odpowiednio pokierować terapią.

Według wytycznych ASHA z 2005 roku, procesy przetwarzania słuchowego odnoszą się nie tylko do odbioru informacji słuchowej w ośrodkowym układzie nerwowym, ale też do wszelkich funkcji neurobiologicznych powiązanych $\mathrm{z}$ tym procesem. W związku $\mathrm{z}$ tym, w bateriach testów diagnostycznych uwzględnia się obecnie zarówno testy behawioralne, jak i elektrofizjologiczne. Wybór testów jest duży, więc audiolog za każdym razem decyduje, które testy zastosować przy diagnozowaniu dziecka. Diagnoza może być poparta także testami elektroakustycznymi i neuroobrazowaniem [Fuente A., McPherson B., 2007].

Do pomiarów elektrofizjologicznych mierzących odpowiedź układu nerwowego na dźwięk, stosowanych w diagnostyce zaliczyć można:

- ABR (auditory brainstem responses) - rejestrację potencjałów wywołanych pnia mózgu,
- MLAP, MLR (Middle Latency Auditory Potential, Middle Latency Responses) - rejestrację średniolatencyjnych potencjałów wywołanych,

- MMN (Mismatch Negativity) - fala niezgodności,

- P300 - rejestracja potencjałów poznawczych (Keith 2004).

Do najczęściej stosowanych testów behawioralnych należą zaś:

- rozumienie mowy w szumie - rozpoznawanie monosylab w obecności sygnału zakłócającego,

- rozumienie mowy filtrowanej - rozpoznawanie monosylab zniekształconych pod względem częstotliwości,

- rozumienie mowy skompresowanej - rozpoznawanie monosylab zniekształconych pod względem czasu prezentacji,

- test integracji obuusznej - rozpoznawanie monosylab, których niskie częstotliwości podawane są do jednego ucha a wysokie do drugiego,

- Masking Level Difference - rozpoznawanie tonów w szumie,

- Dichotic Digit Test - powtarzanie par cyfr podawanych jednocześnie do obu uszu,

- słowa spondejowe - badanie, w którym jednocześnie część słowa jest podawana do jednego ucha a część do drugiego,

- test sekwencji tonów różnej długości, DPT (Duration Pattern Test) - odróżnianie i porządkowanie tonów różniących się długością,

- test sekwencji tonów różnej wysokości, FPT (Frequency Pattern Test) - odróżnianie i porządkowanie tonów różniących się wysokością,

- test rozróżniania przerw pomiędzy bodźcami, GDT (Gap Detection Test) [Fuente \& McPherson 2007].

Do baterii diagnostycznej należy również włączyć diagnozę psychologiczną: ocenę poziomu inteligencji testami werbalnymi lub/i niewerbalnymi oraz ocenę pod kątem ewentualnych zaburzeń zachowania i zaburzeń emocjonalnych.

\section{Formy pomocy}

Umiejętności związane z przetwarzaniem słuchowym rozwijają się stopniowo $\mathrm{z}$ wiekiem, jednak osoby (zwłaszcza dzieci) z zaburzeniami przetwarzania słuchowego potrzebują pomocy w przezwyciężaniu trudności i wypracowywaniu strategii radzenia sobie ze swoimi deficytami. Można im pomóc na różne sposoby w zależności od wielu czynników, takich jak: wiek i możliwości dziecka, współistnienie innych zaburzeń, dostępność środków terapeutycznych. Istnieją trzy obszary, w których można wspierać osobę z CAPD:

- rozwijanie umiejętności słuchowych,

- rozwijanie języka, komunikacji i stymulowanie możliwości poznawczych dziecka,

- poprawa jakości bodźców akustycznych [Shminky \& Baran 1999].

Tę ostatnią można uzyskać zarówno poprzez zmiany wprowadzane $\mathrm{w}$ pomieszczeniach (np. wyłożenie podłogi dywanem, tłumiące pogłos obicia na ścianach), jak i zaopatrzenie dziecka w osobiste urządzenie pozwalające na jednoczesne wzmocnienie głosu osoby mówiącej i redukowanie innych dźwięków otoczenia. Zarówno rodzice jak i nauczyciele mogą również pomagać dziecku mówiąc do 
niego wolno i wyraźnie, podając tą samą informację różnymi słowami (przeformułowując), uzupełniając przekaz słuchowy informacją podawaną drogą wzrokową, itd.

\section{Rozwijanie umiejętności słuchowych dziecka}

Obecnie w Polsce dysponujemy wieloma możliwościami oddziaływań terapeutycznych, które sprzyjają rozwijaniu umiejętności słuchowych dziecka. Należą do nich:

- metoda Tomatisa,

- Indywidualna Stymulacja Słuchu K. Johansena IAS,

- Auricula TM,

- metoda Samonas wg. Ingo Steinbacha,

- Listening Fitness wg. Paula Madaule,

- Trening Integracji Słuchowej (Auditory Integration Trening - AIT) wg. Guya Berarda.,

- terapeutyczne słuchanie,

- Fast For Word,

- metoda Warnkego,

- Interaktywny Metronom,

- logopedyczne, pedagogiczne treningi słuchowe.

\section{Metoda Tomatisa}

Na terapię metodą Tomatisa dzieci są kwalifikowane na podstawie testu uwagi słuchowej i lateralizacji słuchowej oraz/ lub prowadzonego przez terapeutę wywiadu. Na początku terapii pacjentom wykonywany jest szereg testów uzupełniających (badanie lateralizacji funkcjonalnej, zmodyfikowane testy psychologiczne). Sama terapia składa się z sesji, podczas których przez specjalne słuchawki podawany jest odpowiednio opracowany materiał dźwiękowy (na bazie muzyki Mozarta, chorałów gregoriańskich), który następnie przewodzony jest przez kości czaszki i przez powietrze. Materiał ten poddawany jest dodatkowo filtracji i mechanizmowi tzw. 'bramkowania, a ciężar słuchania przerzucany jest stopniowo na prawe ucho. Terapia składa się z dwóch faz: pasywnej i aktywnej. Podczas fazy pasywnej terapii Tomatisa jedynie słucha materiału dźwiękowego. Podczas fazy aktywnej uczestnik stymulowany jest dźwiękami mowy i mobilizowany do ich odtwarzania. Trening ten jest dosyć intensywny. Zaleca się 8 do 10 dwugodzinnych sesji w cyklu. Cykle terapii powinny być oddzielane kilkutygodniowymi przerwami. Liczba i długość cykli zależą od natury problemu, z jakim boryka się dziecko. Terapia metodą Tomatisa prowadzona jest jedynie na terenie ośrodków wyposażonych w odpowiednie urządzenia (elektroniczne ucho, oprogramowanie, słuchawki). Jednak od 2010 r. centrum Tomatisa zaczęło wprowadzać na rynek nowe, przenośne urządzenie do terapii (SOLISTEN ${ }^{\circledR}$ ) (http://www.tomatis.com/; www.ifps.org.pl).

\section{Indywidualna Stymulacja Słuchu K. Johansena (IAS)}

Diagnoza w terapii IAS opiera się na wynikach audiometrii tonalnej. Podczas diagnozowania wykonywane są również testy mowy utrudnionej, w tym test słuchania rozdzielnousznego Na podstawie wyników badań dobierane są odpowiednie moduły dźwiękowe zawierające specjalnie opracowaną, filtrowaną muzykę instrumentalną, zapisywaną na płytach CD. Uczestnik ma za zadanie słuchać nagranego materiału dźwiękowego przez $10 \mathrm{~min}$. dziennie. Korzysta przy tym ze zwykłego, ogólnodostępnego sprzętu audio, zwykłych słuchawek, jakie posiada w domu. Terapia tą metodą trwa od 6 do 10 miesięcy, zależnie od indywidualnych potrzeb. Postępy w terapii kontrolowane są, zależnie od wieku, co 4 do 8 tygodni, a po każdej kontroli pacjent otrzymuje nową płytę $\mathrm{z}$ indywidualnie dobranym programem terapeutycznym (http://www.johansen-ias.pl/).

\section{Auricula Training Method}

Auricula jest treningiem słuchowym połączonym ze stymulacją integracji sensorycznej. W intensywnych, 10-12 dniowych turnusach, aktywnie uczestniczą rodzice, którzy pod okiem terapeuty uczą się jak stymulować różne zmysły dziecka, a następnie wykonują z nim ćwiczenia po powrocie do domu (tzw. program domowy). Podczas treningu dziecko słucha w słuchawkach muzyki i innych przefiltrowanych, zmodyfikowanych elektronicznie dźwięków, które są dostosowywane do jego potrzeb. Jednocześnie uczestnik terapii widzi na komputerze kształty i kolory zsynchronizowane z muzyką. Ta metoda najczęściej wykorzystywana jest $\mathrm{w}$ terapii osób $\mathrm{z}$ autyzmem pomiędzy 3 r.ż. a wiekiem pokwitania. Zależnie od głębokości zaburzenia po ok. 6-9 miesiącach proponowane jest powtórzenie treningu. Ponieważ u podstaw tej terapii leży założenie, że słyszenie, widzenie, odbiór i przetwarzanie informacji oraz mowa tworzą całość, trening ten jest ukierunkowany nie tylko na lokalizację dźwięków i ich rozróżnianie, ale także dzięki powtarzalności bodźców pozwala na prawidłowy odbiór, integrację zmysłową i zrozumienie. (http://www.auricula.org).

\section{Metoda Sonas Samonas według Ingo Steinbacha (SONAS - Spectrally Activated Music of Optimal Natural Structure)}

Metoda SONAS w swoich założeniach nawiązuje do koncepcji prezentowanych przez A. Tomatisa. W terapii stosuje się płyty CD z nagranymi dźwiękami elektronicznymi, utworami klasycznymi oraz odgłosami natury, które są odpowiednio modyfikowane i prezentowane. Dziecko słucha nagranego materiału korzystając z słuchawek Sennheiser HD500A, które nie izolują go od dźwięków otoczenia. Terapeuta określa ile czasu dziennie i jak często w tygodniu dziecko powinno słuchać płyt, kontroluje postępy dziecka co dwa tygodnie i przygotowuje nowy materiał dźwiękowy. W końcowej fazie terapii pacjent słucha przede wszystkim dźwięków prezentowanych przez głośniki (http://www.samonas.com/).

\section{Listening Fitness według Paula Madaule}

Listening Fitness jest domowym programem usprawniania słuchu. Trening posiada fazę pasywnego słuchania oraz aktywnych zadań. Cały program trwa około 10 tygodni, z jedną godzinną sesją słuchania dziennie. Głównym celem treningu jest poprawa kontroli nad głosem i ciałem poprzez ćwiczenia wokalne, tj. gwizdanie, śpiewanie i czytanie do mikrofonu. Program służy do terapii zaburzeń percepcji słuchowej oraz umiarkowanych trudności szkolnych (http://www.listeningfitness.com).

\section{Trening Integracji Słuchowej - (Auditory Integration Trening - AIT) według Guya Berarda}

W treningu AIT stosowane są odpowiednio zmodyfikowane dźwięki pochodzące z muzyki popularnej. Metodę 
wyróżnia losowy sposób prezentacji bodźców, zarówno w odniesieniu do odstępów między dźwiękami, jak i czasu ich trwania. Do stymulacji słuchowej służy sprzęt o nazwie Audiokinetron, którego integralnym elementem są specjalistyczne słuchawki. (http://www.berardaitwebsite.com).

\section{Terapeutyczne słuchanie}

Terapeutyczne słuchanie to trening opracowany na podstawie wyników Alfreda Tomatisa, Guya Berarda i Ingo Steinbacha. W pierwszej części programu do ucha podaje się elektronicznie przetworzony dźwięk o wysokich częstotliwościach, w celu zwiększenia wrażliwości słuchu. W drugim etapie, częstotliwości dopiera się tak, aby zoptymalizować stosunek ilości fal alfa i beta. Oferowany jest specjalny sprzęt do ćwiczeń w domu, pod kontrolą doświadczonego terapeuty. Trening skierowany jest do grup pacjentów z zaburzeniami integracji informacji zmysłowych: przedsionkowych, słuchowych, dotykowych; pacjentów z autyzmem, osób z trudnościami w uczeniu się. Ćwiczenia mają na celu usprawnienie funkcji ruchowych, emocjonalnych i społecznych. (http:// www.terapeutycznesluchanie.pl).

\section{Fast For Word}

Terapia Fast For Word oparta się na koncepcji Ernsta Pöppela dotyczącej percepcji czasu, została rozwinięta i spopularyzowana przez dwa zespoły naukowe kierowane przez Paulę Tallall oraz Michaela Merzenicha. Trening wykonywany jest w oparciu o programy komputerowe dostosowane do różnych grup wiekowych oraz poziomu umiejętności dziecka. Na początku terapii, dziecku prezentuje się dźwięki zwolnione i wydłużone, stopniowo przychodząc do stymulacji coraz bardziej naturalnej. Jednocześnie pacjent rozwiązuje zadania $\mathrm{w}$ postaci gier komputerowych, od 30 do $100 \mathrm{~min}$. dziennie, pięć dni w tygodniu przez okres od 4 do 16 tygodni. Jeśli pacjent radzi sobie dobrze $\mathrm{z}$ wykonywanym ćwiczeniem, program podwyższa stopień trudności. Komputer, z którego korzysta dziecko poddawane terapii, jest podłączony do Internetu, więc informacje zwrotne na temat przebiegu ćwiczeń, ich czasu trwania, postępów i tego, jakie obszary funkcjonowania dziecka wymagają dalszej pracy, szybko trafiają do rodziców i terapeutów w formie generowanych elektronicznie raportów. Programy Fast For Word umożliwiają kształtowanie m.in. umiejętności takich jak identyfikacja dźwięków, rozpoznawanie kolejności, sekwencjonowanie, świadomość fonologiczna, integracja informacji słuchowych i wzrokowych, pamięć (m.in. słuchowej). (http://www.scilearnglobal.com/the-fast-forword-program/)

\section{Metoda Warnkego}

Podczas diagnozy prowadzonej pod kątem zastosowania terapii Warnkego, oceniane jest 14 różnych funkcji (m.in. wzrokowe, słuchowe, motoryczne), w tym stopień ich automatyzacji. Wyniki badań, w postaci rang procentowych odnoszone są do norm wystandaryzowanych dla osób od 5 do 12 r.ż. Większość zadań, które wykonuje uczestnik terapii przypomina proste gry komputerowe, podczas których, jeśli dziecko dobrze sobie radzi, poziom trudności jest stopniowo podwyższany. Ćwiczenia wykonywane podczas terapii służą rozwijaniu i automatyzacji przetwarzania spostrzeżeń wzrokowych, słuchowych oraz zdolności motorycznych, jak również treningowi lateralizacji określonych funkcji. Podczas terapii uczestnik słucha swojego głosu podawanego naprzemiennie do słuchawki lewej i prawej. W terapii używa się przenośnych urządzeń tzw. BrainBoy, z których można korzystać zarówno w domu jak i w ośrodku terapeutycznym. Niektóre wersje tego urządzenia (np. Brain Boy Universal Proffessional) służą zarówno do terapii jak i diagnozy. Do treningu lateralnego wykorzystuje się inne urządzenia: Audio Video Trainer i Lateral Trainer Professional. Trening metodą Warnkego kształtuje m.in. umiejętności: słyszenia kierunkowego, odróżniania wysokości oraz długości dźwięków (tonów), rozpoznawania wzorców (podawanych drogą wzrokową, słuchową), prawidłowego, szybkiego reagowania na bodźce (http://www.metodawarnkego.pl).

\section{Interaktywny Metronom}

Metoda Interaktywny Metronom nawiązuje do koncepcji Pauli Tallal rozwijanych później w pracach zespołu Petera H.Wolffa (Waber i wsp. 2001; Waber i wsp. 2000). Interaktywny metronom to komputerowa wersja tradycyjnego muzycznego metronomu. Terapia ma formę kilkunastogodzinnego programu, po trzy sesje tygodniowo. Dokładna liczba sesji i ich długość dostosowywana jest do możliwości i potrzeb pacjenta. Uczestnik terapii ma za zadanie synchronizować ruchy kończyn (rąk i nóg) z rytmem słyszanym przez słuchawki. Dodatkowo stosuje się stymulację z wykorzystaniem specjalnych rękawic i mat sensorycznych. Prowadzenie terapii wymaga użycia specjalistycznego licencjowanego zestawu audio lub audio-video. Za pomocą tych urządzeń podczas treningu można jednocześnie sprawdzać jakość, jak i precyzję wykonania zadania, tj. różnicę czasu pomiędzy podawanym rytmem a ruchem wykonywanym przez uczestnika. Dzięki temu podczas terapii kształtowane są: planowanie motoryczne, przestrzenna i czasowa analiza struktur rytmicznych jak oraz pamięć sekwencji (bardzo istotna dla rozwoju funkcji językowych) (http://www.interactivemetronome.com).

\section{Logopedyczne i pedagogiczne treningi słuchowe}

Opisane w tej części treningi wykorzystują nie tylko dźwięki sztucznie wygenerowane, ale także dźwięki otoczenia, muzyki i mowy. Podczas treningów wykonuje się ćwiczenia:

- detekcji dźwięku,

- lokalizacji dźwięku,

- rozpoznawania i dyskryminacji (odróżniania):

- natężenia dźwięku,

- wysokości dźwięku,

- długości dźwięku,

- kolejności dźwięków,

- wzorców dźwięków,

- dźwięków zniekształconych,

- dźwięków w obecności sygnału zagłuszającego.

Treningi te wpływają na kształtowanie słuchu fonemowego, fonetycznego i prozodycznego, a także na umiejętności analizy i syntezy sylabowej i głoskowej, poprawiają rozumienie mowy (również zniekształconej oraz w hałasie). Treningi rozwijają również pamięć słuchową, dzięki czemu wpływają na poszerzanie zasobu słownika i poprawę jakości komunikacji. Poprawie może również ulec kontrola słuchowa własnej mowy. 


\section{Podsumowanie}

Obecnie w Polsce istnieje wiele form terapii osób z centralnymi zaburzeniami przetwarzania słuchowego i ich liczba stale się powiększa. Prowadzone są badania i opracowywane nowe, efektywne formy oddziaływań. Nadal jednak nie stworzono metody uniwersalnej, która skutecznie pomagałaby każdemu dziecku. Metody i formy ewentualnej pomocy terapeuta czy lekarz może zatem dobierać kierując się możliwościami dziecka, jego potrzebami i trudnościami. Obserwuje się znaczną skuteczność metod stymulujących polimodalnie tj. Fast For Word, Metoda Warnkego, Interaktywny Metronom. Żadna z opracowanych dotąd metod nie uwzględnia w terapii stanu emocjonalnego dziecka i jego rodziny. Uwzględnienie oddziaływań psychologicznych w terapii osób z centralnymi zaburzeniami przetwarzania słuchowego otwiera nowe perspektywy badań i rozwoju tej dziedziny.

\section{Piśmiennictwo:}

1. American Speech-Language-Hearing Association: Central auditory processing: Current status of research and implications for clinical practice. Am J Audiol, 1996; 5(2): 41-54

2. American Speech-Language-Hearing Association; (Central) auditory processing disorders - the role of the audiologist. American Speech-Language-Hearing Association, 2005; URL:www. asha.org/docs $/ \mathrm{html} /$ PS2005-00114.html, 21.06.2012

3. Chermak G.D., Musiek F.E.: Central auditory processing disorders - New perspectives, Singular Publishing Group Inc.: San Diego, 1997

4. Fuente A., McPherson B.: Ośrodkowe procesy przetwarzania słuchowego: wprowadzenie i opis testów możliwych do zastosowania u pacjentów polskojęzycznych. Otolaryngologia, 2007; 6(2): 66-76

5. Katz J., Stecker N.A. Henderson D.: Central auditory processing: Transdisciplinary view. Mosby Incorporated: St. Louis, 1992; 3-8
6. Keith R.W.: Zaburzenia procesów przetwarzania słuchowego. Otolaryngologia, 2004; 3(1): 7-14

7. Senderski A.: Diagnostyka centralnych zaburzeń przetwarzania słuchowego. Algorytm postępowania diagnostycznego, materiały Instytutu Fizjologii i Patologii Słuchu, 2002

8. Shminky M., Baran J.: Central Auditory Processing Disorders. An overview of Assessment and Management Practices. (W): Reiman J., Malloy P., Klumph R. (red.), Deaf-Blind Perspectives Newsletter, 1999; 7(1): 3-7

9. Waber D.P., Weiler M.D., Bellinger D.C. i wsp.: Diminished motor timing control in children referred for diagnosis of learning problems. Developmental Neuropsychology, 200; 17(2): 181-97

10. Waber D.P., Weiler M.D., Wolff P.H. i wsp.: Processing of rapid auditory stimuli in school-age children referred for evaluation of learning disorders. Child Development, 2001; 72(1): 37-49 